\title{
ENDEMIC PEMPHIGUS FOLIACEUS (FOGO SELVAGEM) AND PEMPHIGUS VULGARIS: IMMUNOGLOBULIN G HETEROGENEITY DETECTED BY INDIRECT IMMUNOFLUORESCENCE
}

Valéria Aoki, Milian H. T. Huang, Alexandre M. Périgo, Lígia M. I. Fukumori, Celina W. Maruta, Claudia G. Santi, Zilda N. P. Oliveira and Evandro Rivitti

AOKI V et al. Endemic pemphigus foliaceus (fogo selvagem) and pemphigus vulgaris: immunoglobulin G heterogeneity detected by indirect immunofluorescence. Rev. Hosp. Clín. Fac. Med. S. Paulo 59(5):251-256, 2004.

Pemphigus are autoimmune intraepidermal blistering diseases in which immunoglobulin G (IgG) autoantibodies are directed against desmosomal glycoproteins. The aim of this study was to determine the IgG subclass profile of endemic pemphigus foliaceus (fogo selvagem) and pemphigus vulgaris utilizing indirect immunofluorescence.

PATIENTS AND METHODS: Twenty-five patients with pemphigus vulgaris, 25 with endemic pemphigus foliaceus (fogo selvagem), and 25 healthy controls were analyzed by indirect immunofluorescence for circulating autoantibodies (total $\mathrm{IgG}$ and its subclasses).

RESULTS: Our data revealed a significant correlation $(P<.05)$ of disease activity and autoantibody levels in both forms of pemphigus, i.e., negative titers related to clinical remission, whereas positive results related to active disease. Immunoglobulin $\mathrm{G}$ subclass analysis in fogo selvagem demonstrated that in patients in remission, 56\% showed positive immunoglobulin G4; in active disease, immunoglobulin G4 was the predominant subclass (100\% positive in all cases). The IgG subclass profile in pemphigus vulgaris showed that in patients in remission, only $10 \%$ were positive for immunoglobulin G4; in active disease, positivity for immunoglobulin G4 was present in $78 \%$ to $88 \%$ of the cases.

CONCLUSION: Subclass characterization of immunoglobulin G autoantibodies is a useful tool for pemphigus followup, since immunoglobulin G4 (IgG4) is the subclass that is closely related to recognition of pathogenic epitopes, and consequently with disease activity. Careful monitoring should be performed for fogo selvagem in clinical remission with a homogeneous IgG4 response, since this may indicate more frequent relapses.

KEY WORDS: Pemphigus vulgaris. Pemphigus foliaceus. Fogo selvagem. Autoimmunity. Immunofluorescence.

Pemphigus are autoimmune blistering diseases in which immunoglobulin $\mathrm{G}(\mathrm{IgG})$ antibodies are directed against desmogleins (desmosomal glycoproteins), leading to cell-cell detachment and acantholysis. ${ }^{1}$ They are classified as 6 different types $\left.{ }^{2,3}: 1\right)$ pemphigus foliaceus (erythematosus, classic and endemic or fogo selvagem); 2) pemphigus vulgaris (variant: vegetans); 3) drug-induced pemphigus; 4) paraneoplastic pemphigus; 5) IgA pemphigus; 6) herpetiform (clinical variant of either pemphigus vulgaris or foliaceus). Endemic pemphigus foliaceus (EPF) or fogo selvagem (FS) shares the same clinical, histologic, and immunological profile

From the Department of Dermatology and Immunodermatopathology Laboratory, Hospital das Clínicas, Faculty of Medicine, University of São Paulo - São Paulo/SP, Brazil.

E-mail: valaoki@hotmail.com Received for publication on February 02, 2004. of the classic form, showing, however, unique epidemiological features, such as presence of familial cases and a high prevalence in South America, especially in Brazil. ${ }^{4-7}$

Humoral response in pemphigus vulgaris (PV) and fogo selvagem (FS) is mediated by $\operatorname{IgG}$ autoantibodies. ${ }^{7,8}$ In PV, it has been demonstrated that this response is predominantly of the IgG4 subclass in active cases, and IgG1 is the subclass involved in disease remission. ${ }^{9-11}$ The profile of $\operatorname{IgG}$ 
subclass autoimmune response in FS is similar to PV, showing an IgG4 response in active disease and IgG1 in preclinical stages or in disease remission. ${ }^{11-15}$

Recent studies ${ }^{13}$ have shown that due to an intramolecular epitope spreading of desmoglein 1, the autoantigen involved in FS, there is a heterogeneous IgG subclass response in this disease. In preclinical stages and in clinical remission of FS, IgG1 autoantibodies are directed to the carboxy terminal EC-5 of desmoglein 1. Disease onset correlates with an IgG subclass switch (from IgG1 to IgG4), and IgG4 autoantibodies recognize other epitopes of the desmoglein molecule, the EC1-2 amino-terminal domains.

The aim of our study was to analyze, utilizing the indirect immunofluorescence method, the IgG subclass profile of patients diagnosed with pemphigus vulgaris and fogo selvagem who were followed up at the Hospital das Clínicas, Department of Dermatology, University of São Paulo, São Paulo, Brazil.

\section{MATERIAL AND METHODS}

\section{Source of Sera}

Twenty-five patients with pemphigus vulgaris, 25 with fogo selvagem, and 25 healthy controls were selected to enter this study. The diagnosis of pemphigus was made according to clinical examination, histopathologic, and direct immunofluorescence analysis. All patients included were followed up at the outpatient clinic, Hospital das Clínicas, Department of Dermatology, University of São Paulo, from August 2002 to October 2003.

In the PV group $(\mathrm{n}=25), 18(72 \%)$ were female and 7 (28\%) were male. Age varied from 23 to 83 years, with a mean age of 51 years. Clinical forms were distributed as follows: $10(40 \%)$ were in remission, 9 (36\%) had localized lesions (oral mucosa and/ or scalp), and 6 (24\%) had generalized disease.

In the FS group $(\mathrm{n}=25), 15(60 \%)$ were female and $10(40 \%)$ were male. Age varied from 15 to 79 years, with a mean age of 38 years. Clinical forms were distributed as follows: $9(36 \%)$ were in remission, 4 (16\%) had localized lesions, and 12 (48\%) had generalized disease.

Blood drawing was performed after patients' consent, and serum was separated and stored at $-20^{\circ} \mathrm{C}$ until testing.

\section{Indirect Immunofluorescence (Total IgG)}

All sera were tested by indirect immunofluorescence (IIF) using normal human foreskin as the substrate. Skin cryosections of $4 \mu$ on albuminized slides were incubated for 30 minutes with serial serum dilutions (in Trizma acetate-buffered saline (TBS), $\mathrm{pH} 7.5$, with calcium added, or TBS-Ca ${ }^{++}$), starting at 1:20, room temperature. Two 10-minute washes with the same buffer, followed by incubation with the secondary antibody (goat anti-human IgG-FITC, Sigma, USA) at a 1:130 dilution, were performed. Two more washes with TBS-Ca+ ${ }^{++}$were made before mounting slides with buffered glycerin ( $\mathrm{pH}$ 9.0/0.5M). Slides were then analyzed using the epiluminescence microscope (Zeiss, 160 and 400X).

\section{Indirect Immunofluorescence (IgG Subclasses)}

All sera were tested by indirect immunofluorescence using normal human foreskin as the substrate. Skin cryosections of $4 \mu$ on albuminized slides were incubated for 30 minutes with serial serum dilutions (in Trizma acetate-buffered saline (TBS), $\mathrm{pH} 7.5$, with calcium added, or TBS-Ca ${ }^{++}$), starting at 1:20, room temperature. Two 10-minute washes with the same buffer was followed by an incubation with the secondary antibody (mouse antihuman $\operatorname{IgG1,2,3,4~Sigma,~USA),~at~a~}$ 1:500 dilution for $\operatorname{IgG1}, 2$, and 3 , and 1:1000 for IgG4. Two more washes with TBS-Ca ${ }^{++}$were made, followed by the last 30-minute incubation with the conjugate rabbit antimouse-FITC (Dako, Denmark) at a 1:30 dilution. Final steps included two 10-minute washes with $\mathrm{TBS}-\mathrm{Ca}^{++}$and mounting slides with buffered glycerin $(\mathrm{pH} 9.0 /$ $0.5 \mathrm{M})$. Results were analyzed using an epiluminescence microscope (Zeiss, 160 and 400X).

\section{Statistical Analysis}

Category variables were presented in descriptive form in tables with absolute and relative frequencies. Proportions were compared utilizing Pearson's $\chi^{2}$ test or Fisher's test, when the former could not be applied. Values below $P=.05$ were considered statistically significant.

\section{RESULTS}

\section{Total IgG Autoantibodies in Pemphi- gus Vulgaris (PV)}

In $\mathrm{PV}, \mathrm{IgG}$ autoantibodies by IIF demonstrated the following pattern (Table 1):

1) $\mathrm{PV}$ in remission $(\mathrm{n}=10): 70 \%$ negative, $30 \%$ positive, titers ranging from $1: 80$ to $1: 320$ ).

2) PV, localized form $(n=9): 11.1 \%$ negative, $88.9 \%$ positive, titers ranging from $1: 160$ to $1: 1280)$.

3) $\mathrm{PV}$, generalized form $(\mathrm{n}=6)$ : $16.7 \%$ negative, $83.3 \%$ positive, titers ranging from 1:80 to 1:1280).

There was a clear correlation between autoantibody titers and clinical presentation, i.e., negative titers corre- 
late with disease in remission, whereas positive results correlate with disease activity.

\section{Total IgG Autoantibodies in Fogo Selvagem (FS)}

In FS, IgG autoantibodies by IIF demonstrated the following pattern (Table 2):

1) FS in remission $(n=9)$ : $67 \%$ negative, $33 \%$ positive, titers ranging from $1: 80$ to $1: 320)$.

2) FS, localized form $(n=4)$ : $0 \%$ negative, $100 \%$ positive, titers ranging from $1: 160$ to $1: 2560$ ).

3) FS, generalized form $(n=12): 0 \%$ negative, $100 \%$ positive, titers ranging from 1:80 to 1:5120).

There was a clear correlation between autoantibody titers and clinical presentation, i.e., negative titers correlate with disease in remission, whereas positive results correlate with disease activity.

IgG Subclasses in Pemphigus Vulgaris (PV)

In PV, IgG subclass analysis by IIF revealed the following findings:

1) $\mathrm{PV}$ in remission $(\mathrm{n}=10): 50 \%$ showed negative results for all sub- classes, 20\% were IgG1-positive, 20\% had IgG1 and IgG4 antibodies, and only $10 \%$ were exclusively IgG4-positive (Figure 3); in Table 3 , the analysis of each IgG subclass shows that $70 \%$ were IgG4-negative, and $40 \%$ were IgG1-positive.

2) PV, localized form $(\mathrm{n}=9)$ : IgG4 was the only subclass present and was positive in $78 \%$ of the cases. (Table 4)
3) PV, generalized form $(n=6): \operatorname{IgG} 4$ was present in $83 \%$ of the patients, and $\mathrm{IgG} 1$ and $\mathrm{IgG} 2$ were present only in $17 \%$ of the patients. (Table 5).

\section{IgG Subclasses in Fogo Selvagem (FS)}

In FS, IgG subclass analysis by IIF revealed the following findings:

Table 1 - Statistical analysis of the different clinical forms of pemphigus vulgaris (PV) and indirect immunofluorescence (IIF) with total IgG (Fisher's exact test; significant results when $P<.05)$.

\begin{tabular}{lcccccc}
\hline IIF & $\begin{array}{c}\text { Localized, } \\
\text { active } \\
\text { PV }\end{array}$ & Frequency & $\begin{array}{c}\text { Generalized, } \\
\text { active } \\
\text { PV }\end{array}$ & Frequency & $\begin{array}{c}\text { PV in } \\
\text { remission }\end{array}$ & Frequency \\
\hline Negative & 1 & $11.1 \%$ & 1 & $16.7 \%$ & 7 & $70 \%$ \\
Positive & 8 & $88.9 \%$ & 5 & $83.3 \%$ & 3 & $30 \%$ \\
Total & 9 & $100.0 \%$ & 6 & $100.0 \%$ & 10 & $100.0 \%$ \\
\hline
\end{tabular}

$P=.0214$

Table 2 - Statistical analysis of the different clinical forms of fogo selvagem (FS) and indirect immunofluorescence (IIF) with total IgG (Fisher's exact test; significant results when $P<.05)$.

\begin{tabular}{lcccccc}
\hline IIF & $\begin{array}{c}\text { Localized, } \\
\text { active } \\
\text { FS }\end{array}$ & Frequency & $\begin{array}{c}\text { Generalized, } \\
\text { active } \\
\text { FS }\end{array}$ & Frequency & $\begin{array}{c}\text { FS in } \\
\text { remission }\end{array}$ & Frequency \\
\hline Negative & 0 & $0.0 \%$ & 0 & $0.0 \%$ & 6 & $67 \%$ \\
Positive & 4 & $100.0 \%$ & 12 & $100.0 \%$ & 3 & $33 \%$ \\
Total & 4 & $100.0 \%$ & 12 & $100.0 \%$ & 9 & $100.0 \%$ \\
\hline
\end{tabular}

$P=.0011$

Table 3 - Statistical analysis of pemphigus vulgaris under remission and indirect immunofluorescence (IIF) with IgG subclasses (Fisher's exact test; significant results when $P<.05$ ).

\begin{tabular}{lcccccccc}
\hline IIF & IgG1 & Frequency & IgG2 & Frequency & IgG3 & Frequency & IgG4 & Frequency \\
\hline Negative & 6 & $60.0 \%$ & 10 & $100.0 \%$ & 10 & $100.0 \%$ & 7 & $70.0 \%$ \\
Positive & 4 & $40.0 \%$ & 0 & $0.0 \%$ & 0 & $0.0 \%$ & 3 & $30.0 \%$ \\
Total & 10 & $100.0 \%$ & 10 & $100.0 \%$ & 10 & $100.0 \%$ & 10 & $100.0 \%$ \\
\hline
\end{tabular}

$P=.0411$

Table 4 - Statistical analysis of active, localized pemphigus vulgaris and indirect immunofluorescence (IIF) with IgG subclasses (Fisher's exact test; significant results when $P<.05$ ).

\begin{tabular}{lcccccccc}
\hline IIF & IgG1 & Frequency & IgG2 & Frequency & IgG3 & Frequency & IgG4 & Frequency \\
\hline Negative & 9 & $100.0 \%$ & 9 & $100.0 \%$ & 9 & $100.0 \%$ & 2 & $22 \%$ \\
Positive & 0 & $0.0 \%$ & 0 & $0.0 \%$ & 0 & $0.0 \%$ & 7 & $78 \%$ \\
Total & 9 & $100.0 \%$ & 9 & $100.0 \%$ & 9 & $100.0 \%$ & 9 & $100.0 \%$ \\
\hline
\end{tabular}

$P<.001$ 
1) FS in remission $(n=9): 56 \%$ showed positive results, all of them with an exclusive IgG4 response. (Table 6)

2) FS, localized form $(n=4)$ : IgG4 was present in all patients $(100 \%)$, contrasting with $\operatorname{IgG} 1$, which was present in only $25 \%$ of the samples. (Table 7)

3) FS, generalized form $(n=12): \operatorname{IgG} 4$ was also present in $100 \%$ of the patients, IgG1 and IgG2 were present in $33 \%$ of the patients, and IgG3 was positive in $17 \%$ of the patients. (Table 8)

\section{Total IgG and Subclasses in Healthy Controls}

All sera showed negative results.

\section{DISCUSSION}

Autoimmunity is the result of a loss of self-tolerance, and depends on multiple interacting factors, such as genetics, infections, mechanical injuries, lymphocyte alterations, and hormones. $^{11}$

Intercellular adhesion of the epi- dermis is a vital function. When the self-tolerance mechanism is broken down, cell-cell detachment occurs due to the binding of autoantibodies to epidermal autoantigens, resulting in blister formation.

Pemphigus are considered auto-immune blistering diseases in which the target antigens are glycoproteins located on the desmosomal core, the socalled desmogleins, ${ }^{16-19}$ which belong to the cadherins superfamily and are calcium-dependent adhesion molecules. ${ }^{17,20,21} \operatorname{IgG}$ autoantibodies in the epidermis and in the sera of pemphi-

Table 5 - Statistical analysis of active, generalized pemphigus vulgaris and indirect immunofluorescence (IIF) with IgG subclasses (Fisher's exact test; significant results when $P<.05$ ).

\begin{tabular}{lcccccccc}
\hline IIF & IgG1 & Frequency & $\operatorname{IgG} 2$ & Frequency & IgG3 & Frequency & IgG4 & Frequency \\
\hline Negative & 5 & $83.3 \%$ & 5 & $83.3 \%$ & 5 & $83.3 \%$ & 1 & $16.7 \%$ \\
Positive & 1 & $16.7 \%$ & 1 & $16.7 \%$ & 1 & $16.7 \%$ & 5 & $83.3 \%$ \\
Total & 6 & $100.0 \%$ & 6 & $100.0 \%$ & 6 & $100.0 \%$ & 6 & $100.0 \%$ \\
\hline
\end{tabular}

$P=.0293$

Table 6 - Statistical analysis of fogo selvagem in remission, and indirect immunofluorescence (IIF) with IgG subclasses (Fisher's exact test; significant results when $P<.05$ ).

\begin{tabular}{lcccccccc}
\hline IIF & IgG1 & Frequency & IgG2 & Frequency & IgG3 & Frequency & IgG4 & Frequency \\
\hline Negative & 9 & $100.0 \%$ & 9 & $100.0 \%$ & 9 & $100.0 \%$ & 4 & $44 \%$ \\
Positive & 0 & $0.0 \%$ & 0 & $0.0 \%$ & 0 & $0.0 \%$ & 5 & $56 \%$ \\
Total & 9 & $100.0 \%$ & 9 & $100.0 \%$ & 9 & $100.0 \%$ & 9 & $100.0 \%$ \\
\hline
\end{tabular}

$P=.0013$

Table 7 - Statistical analysis of fogo selvagem in remission, and indirect immunofluorescence (IIF) with IgG subclasses (Fisher's exact test; significant results when $P<.05$ ).

\begin{tabular}{lcccccccc}
\hline IIF & IgG1 & Frequency & IgG2 & Frequency & IgG3 & Frequency & IgG4 & Frequency \\
\hline Negative & 4 & $100 \%$ & 4 & $100.0 \%$ & 4 & $100.0 \%$ & 0 & $0.0 \%$ \\
Positive & 0 & $0.0 \%$ & 0 & $0.0 \%$ & 0 & $0.0 \%$ & 4 & $100.0 \%$ \\
Total & 4 & $100.0 \%$ & 4 & $100.0 \%$ & 4 & $100.0 \%$ & 4 & $100.0 \%$ \\
\hline
\end{tabular}

$P=.0110$

Table 8 - Statistical analysis of generalized fogo selvagem, and indirect immunofluorescence (IIF) with IgG subclasses (Fisher's exact test; significant results when $P<.05$ ).

\begin{tabular}{lccccccc}
\hline IIF & IgG1 & Frequency & IgG2 & Frequency & IgG3 & Frequency & IgG4 \\
\hline Negative & 8 & $67 \%$ & 8 & $67 \%$ & 10 & $83 \%$ & 0 \\
Positive & 4 & $33 \%$ & 4 & $33 \%$ & 2 & $17 \%$ \\
Total & 12 & $100.0 \%$ & 12 & $100.0 \%$ & 12 & $100.0 \%$ & 12 \\
\hline
\end{tabular}

$P<.001$ 
gus vulgaris and foliaceus patients were demonstrated by Beutner \& Jordon decades ago. ${ }^{18-19}$ The pathogenicity of these autoantibodies was confirmed years later in animal models, ${ }^{5,19}$ in which these diseases were reproduced when injected with $\operatorname{IgG}$ from patients with PV or FS.

A clear correlation of IgG autoantibody titers and pemphigus activity has been reported by other authors. ${ }^{9,15,19,22}$ Our study corroborated these data, i.e., the presence of circulating $\operatorname{IgG}$ is usually related to disease activity. In PV, $70 \%$ had a negative IIF with total $\mathrm{IgG}$ in cases in remission, and IIF was positive in $87 \%$ of active cases. In FS, $67 \%$ of the patients in remission had a negative IIF with total $\mathrm{IgG}$, and all active cases showed total IgG deposits. Higher titers were observed in FS patients in comparison to PV patients: $16 \%$ of FS patients showed IIF titers above 1:1280, especially when patients presented a generalized form.

The determination of IgG subclasses in pemphigus is a very interesting point. Studies demonstrate the predominance of $\mathrm{IgG} 4$ and $\mathrm{IgG} 1$ isotypes ${ }^{9,10,12,15}$ in both forms of pemphigus, with a major role of IgG4 in disease activity. ${ }^{9-10,12-13,15}$

Recent data focusing on epitope mapping ${ }^{13}$ of desmoglein 1 (FS auto- antigen) show that intramolecular epitope spreading may be responsible for this IgG subclass switch: in the preclinical or remission phase of the disease, there is a production of $\mathrm{IgG1}$ autoantibodies directed against the EC-5 carboxyl portion of desmoglein 1. This condition changes when the disease becomes active, and an IgG4oriented response starts, targeting other portions of the molecule (EC1-2), which are located on the amino-terminal side of desmoglein 1. Factors that may lead to this $\operatorname{IgG}$ switch include genetics and environmental aspects, which may play a crucial role in FS. ${ }^{5,13}$

Our findings in IgG subclass distribution by IIF in active PV and FS are also in accordance with other reports ${ }^{13-}$ ${ }^{15,19}$; IgG4 is the predominant subclass in active disease, showing an $80 \%$ sensitivity in PV, and a $100 \%$-sensitivity in FS.

Interesting findings in our data are related to those PV and FS patients in remission, since they show different patterns of $\mathrm{IgG}$ isotypes. In FS, our findings revealed that these patients had anti-IgG4 autoantibodies, despite the absence of cutaneous lesions. Our findings demonstrate a different profile from that shown by Warren et al., ${ }^{12}$ who found a negative IgG4 anti-Dsg1 response in 6 out of $8 \mathrm{FS}$ patients, and a positive $\operatorname{IgG} 1$ anti-Dsg1 response in 5 out of 8 FS patients in clinical remission by ELISA.

We propose a closer follow-up of our FS patients, since they are more prone to experiencing reactivation of the disease, according to their IgG subclass pattern. In contrast, our PV patients in clinical remission show a distinct IgG subclass profile, with only $10 \%$ showing exclusive IgG4 response. This may indicate that PV patients, once in clinical remission, will tend to have less disease reactivation.

FS is the only auto-immune blistering disease with endemic features; the finding of an exclusive IgG4-based response in patients in clinical remission suggests that these patients may be under a constant environmental trigger, ${ }^{5,12,-3}$ which, in association with a genetic predisposition, may lead to the production of pathogenic autoantibodies.

Our analysis indicates that monitoring $\operatorname{IgG}$ autoantibodies in pemphigus vulgaris or foliaceus (fogo selvagem) of patients in clinical remission is a very important matter, especially if subclass characterization is performed. Further studies with an ELISA technique utilizing recombinant desmogleins will be necessary to improve the determination of $\mathrm{IgG}$ isotypes in the humoral response of our pemphigus patients.

\section{RESUMO}

AOKI V e col. Pênfigo foliáceo endêmico (fogo selvagem) e pênfigo vulgar: hetregeneidade da imunoglobulina $\mathrm{G}$ detectada através da imunofluorescência indireta. Rev. Hosp. Clín. Fac. Med. S. Paulo 59(5):251-256, 2004.

Pênfigos são enfermidades autoimunes bolhosas intraepidérmicas, onde auto-anticorpos IgG se dirigem contra glicoproteínas desmossomais. $\mathrm{O}$ objetivo deste estudo foi determinar o perfil de subclasses de imunoglubulina $G$ no pênfigo foliáceo endêmico (fogo selvagem) e no pênfigo vulgar através da imunofluorescência indireta.

MÉTODOS: Vinte e cinco doentes de pênfigo foliáceo endêmico (fogo selvagem), 25 de pênfigo vulgar e 25 controles sadios foram analisados atra- vés da imunofluorescência indireta, com respeito aos auto-anticorpos circulantes (imunoglobulina $\mathrm{G}$ total e subclasses).

RESULTADOS: Nossos dados mostram uma correlação estatisticamente significativa $(\mathrm{p}<0.05)$ entre atividade da doença e títulos de autoanticorpos circulantes em ambas as formas de pênfigo, ou seja, títulos negativos relacionaram-se com remissão 
clínica, enquanto resultados positivos correlacionaram-se com doença em atividade. A análise de subclasses de IgG mostrou que $56 \%$ dos doentes de fogo selvagem em remissão apresentaram apenas IgG4 positiva; na doença ativa, IgG4 foi a subclasse predominante, sendo positiva em $100 \%$ dos casos. Nos doentes de pênfigo vulgar, apenas $10 \%$ dos doentes em remissão apresentaram positividade exclusiva para
IgG4; na doença em atividade, IgG4 esteve presente em $78-83,3 \%$ dos casos.

CONCLUSÕES: A caracterização de subclasses de imunoglobulina $G$ consiste em um instrumento de grande valia no seguimento de doentes de pênfigo, uma vez que a IgG4 é a subclasse intimamente relacionada com o reconhecimento de epítopos patogênicos, e consequentemente com atividade da enfermidade. No fogo selvagem em remissão com uma resposta homogênea 'as custas de IgG4, uma monitoração cuidadosa deve ser realizada, uma vez que isto pode significar uma maior chance de reativação.

UNITERMOS: Pênfigo vulgar. Pênfigo Foliáceo. Fogo Selvagem. Auto-imunidade. Imunofluorescência.

\section{REFERENCES}

1. Stanley JR. Pemphigus. In: Fitzpatrick's Dermatology in General Medicine. $6^{\text {th }}$ edition. USA: Ed. Mc Graw Hill; 2003. p. 55874.

2. Santi CG, Maruta CW, Aoki V, Sotto MN, Rivitti EA, Diaz LA. Pemphigus herpetiformis is a rare, clinical expression of nonendemic pemphigus foliaceus, fogo selvagem and pemphigus vulgaris. J Am Acad Dermatol 1996;34:40-6.

3. Amagai M. Adhesion molecules. I: Keratinocyte-keratinocyte interactions: cadherins and pemphigus. Progress in Dermatology. J Invest Dermatol 1995;104:146-52.

4. Warren SJP, Lin MS, Giudice GJ, Hoffmann RG, Hans-Filho G, Aoki V, et al. The prevalence of antibodies against desmoglein 1 in endemic pemphigus foliaceus in Brazil. N Engl J Med 2000;343:23-30.

5. Aoki V, Millikan RC, Rivitti EA, Hans-Filho G, Eaton DP, Warren SJP, et al.Environmental risk factors of Fogo Selvagem. J Investig Dermatol Symp Proc 2004; 9:34-40.

6. Lombardi C, Borges PC, Chaul A, Sampaio SAP, Rivitti EA, Friedman $\mathrm{H}$, et al. Environmental risk factors in endemic pemphigus foliaceus (fogo selvagem). J Invest Dermatol 1992;98:847-50.

7. Sampaio SAP, Rivitti EA, Aoki V, Diaz LA. Brazilian pemphigus foliaceus, endemic pemphigus foliaceus or fogo selvagem (wild fire). Contemporary Tropical Dermatology 1994;12(4):765-76.

8. Diaz LA, Sampaio SAP, Rivitti EA, Martins CR, Cunha PR, Lombardi C, et al. Endemic pemphigus foliaceus (fogo selvagem): I. Clinical features and immunopathology. J Am Acad Dermatol 1989;20:657-9.

9. Bhol K, Ahmed RA. Correlation of subclasses of IgG with disease activity in pemphigus vulgaris. Dermatology 1994; 189(suppl $1): 85-89$.

10. Bhol K, Natarajan K, Nagarwalla N, Mohimen A, Aoki V, Ahmed RA. Correlation of peptide and IgG subclass with pathogenic and nonpathogenic autoantibodies in pemphigus vulgaris: A model for autoimmunity. Proc Natl Acad Sci USA 1995;92:5239-43.
11. Hacker MK, Janson M, Fairley JA, Lin MS. Isotypes and antigenic profiles of pemphigus foliaceus and pemphigus vulgaris autoantibodies. Clin Immunol 2002;105(1):64-74.

12. Warren SJP, Arteaga L, Rivitti EA, Aoki V, Hans-Filho G, Qaqish $\mathrm{BF}$, et al. The role of IgG subclass switch in the pathogenesis of fogo selvagem. J Invest Dermatol 2003;120:104-8.

13. Li N, Aoki V, Hans-Filho G, Rivitti EA, Diaz LA. The role of intramolecular epitope spreading in the pathogenesis of endemic pemphigus foliaceus (fogo selvagem). J Exp Med 2003;197(11):1501-10.

14. Santos SNMB, Patrus AO, Filgueira AL, Diaz LA. Perfil evolutivo das subclasses de imunoglobulinas gama em pacientes de pênfigo foliáceo endêmico. An Bras Dermatol 2001;76(5):561-74.

15. Rock B, Martins CR, Theophilopoulos AN, Diaz LA. The pathogenic effect of IgG autoantibodies in endemic pemphigus foliaceus (fogo selvagem). N Engl J Med 1989;320:1463-9.

16. Amagai M, Klaus-Kotvun V, Stanley JR. Autoantibodies against a novel epithelial cadherin in pemphigus vulgaris, a disease of cell adhesion. Cell 1991;67:869-77.

17. Buxton RS, Magee AI. Structure and Interactions of Desmosomal and Other Cadherins. Cell 1992;3:157-167.

18. Fine, DJ. Pemphigus vulgaris, foliaceus, and paraneoplastic. Topics in Clinical Dermatology: Bullous Diseases. New York- Tokyo: IGAKU-SHOIN; 1993. p. 52-74.

19. Aoki V. Avaliação da técnica de imunoprecipitação com a desmogleína 1 recombinante em população de risco para o pênfigo foliáceo endêmico (fogo selvagem). 80p. Doctoral Thesis (Doutorado em Medicina) 1999 - Faculdade de Medicina, Universidade de São Paulo, São Paulo. Brasil.

20. Goodwin L, Hill JE, Raynor K, Raszi L, Manabe M, Cowin P. Desmoglein shows extensive homology to the Cadherin Family of Cell Adhesion Molecules. Bioch Biophys Res Commun1990; 173: $1224-1230$

21. Koch PJ, Walch MJ, Schmelz M, Goldschmidt MD, Zimbelmann R, Franke WW. Identification of desmoglein, a constitutive desmosomal glycoprotein, as a member of the cadherin family of cell adhesion molecules. Eur J Cell Biol 1990; 53:1-12. 